\title{
A Prevalence Study of Ectoparasites on the Long-Eared Hedgehog (Hemiechinus Auritus) in Sohag Governorate, Egypt
}

\author{
Abd El-Aleem S. S. Desoky ${ }^{{ }^{*}}$, A.M. Fahmy ${ }^{2}$, M.M. Abd-Allah ${ }^{3}$ \\ ${ }^{1}$ Plant protection Department (Agricultural Zoology), Faculty of Agriculture, Sohag University, Egypt. \\ ${ }^{2}$ Plant Protection Dept., Fac. Agri. and Natural Resources, Aswan University, Egypt. \\ ${ }^{3}$ Plant Protection Department, Faculty of Agriculture, Sohag University, Egypt.
}

*Corresponding Author: Abd El-Aleem S. S. Desoky, Plant protection Department (Agricultural Zoology), Faculty of Agriculture, Sohag University, Egypt

\begin{abstract}
Samples of long eared hedgehog Hemiechinus auritus were collected from Sohag area, in the spring 2019. The study show that the long eared hedgehog that was infected by 2 ticks, Rhipicephalus Turanicus, Hyalomma sp., and one of fleas, Leptopsylla segnis.
\end{abstract}

\section{INTRODUCTION}

Hedgehogs are small, nocturnal and spiny-coated mammals which are found in synanthropic environments and they are kept as pets by some people (Mizgajska-Wiktor et al., 2010 \& Silaghi et al., 2012). As hedgehogs feed on insects, worms, centipedes, snails, mice, frogs, lizards and snakes, they are considered as useful animals for natural ecosystems and are in the protected species list (MizgajskaWiktor et al., 2010). They are ideal hosts for ecto and endoparasites, because they have active foraging behavior and do not groom themselves (Foldvari et al., 2011). On the other hand, these animals can serve as reservoir for some zoonotic pathogens. Hedgehogs acquire some pathogens through tick or flea bites and are involved in the endemic cycle of these pathogens. Keeping in mind that Hedgehogs are known as potential host for some variants of Anaplasma phagocytophilum, tick-born encephalitis virus (TBEV), Rickettsia felis, Eucoleus aerophilus, causative agent of pulmonary infection which resembled a bronchial carcinoma and at least four species of Lyme spirochetes (Foldvari, et al. 2011 \& McCarthy and Moore 2000 \& Silaghi, et al. 2012). The hedgehogs have become popular in recent years among pet owners and these animals have benefits and potential hazards for their owners. Some studies have been conducted on ecto and endoparasites and some other on zoonotic pathogens in hedgehogs around the world (Foldvari et al. 2011\& Silaghi, et al. 2012)

\section{MATerials And Methods}

This study was carried out in the Sohag District at the Village of Awlad Naseer - Naja Tarkhan at the north of the Sohag Governorate about $2 \mathrm{~km}$. Many samples were collected of long eared hedgehog Hemiechinus auritus during the spring 2019 by some metal traps and direct catching during the night (Activation period). The live animals were brought to the laboratory at the Agricultural Animal Laboratory at the Faculty of Agriculture, Sohag University. In the laboratory, live hedgehogs were anaesthetized by using ether or chloroform in a glass container. The body surface of each hedgehog was carefully searched for ectoparasites. The collected arthropods were preserved in $70 \%$ alcohol in internally labeled bottles. Using a stereoscopic microscope, they were then identified to species level according to the identification keys as well as by comparison with voucher specimens (Walker et al., 2007).

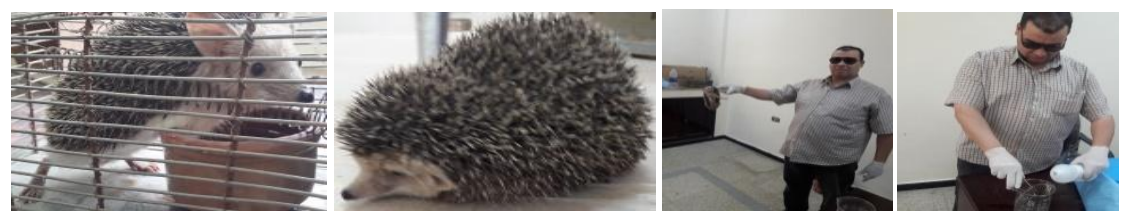

Photo1. Long-eared hedgehog (Hemiechinus auritus) in the Agricultural Animal Laboratory at the Faculty of Agriculture, Sohag University. 


\section{RESULTS AND DISCUSSION}

From this study results ( Table1) shown a total of long-eared hedgehogs were infected by 2 ticks, Rhipicephalus Turanicus, Hyalomma sp., and one of fleas, Leptopsylla segnis. These animals can serve as reservoir for some zoonotic pathogens. Hedgehogs acquire some pathogens through tick or flea bites and are involved in the endemic cycle of these pathogens. And while the hedgehogs have become popular in recent years among pet owners and these animals have benefits and potential hazards for their owners. So we need more studies are needed to find out hedgehog ectoparasites in other parts of Egypt.

\subsection{Our Results Similar with}

- Nematollahi, et al. (2014) In Iran, they concluded the hedgehogs harbored the adults of two ixodidae tick species belonging to two genera, namely Hyalomma excavatum and Rhipicephalus turanicus as well as two flea species of two genera, namely Ctenocephalides canis and Leptopsylla segnis.

- (Jassim, 2017) In Iraq, found that a long-eared hedgehog was infected by Rhipicephalus turanicus, this shows that Rhipicephalus especially $R$. turanicus. It is widely found in wild animals, especially on hedgehogs with high rate.

Table1. Detailed data for ectoparasites found on examined hedgehogs in the current study.

\begin{tabular}{|c|c|c|}
\hline Ectoparasites & Found/ Absence & Species \\
\hline Lice & - & \\
\hline Fleas & + & Leptopsylla segnis \\
\hline Mites & - & \\
\hline Ticks & + & $\begin{array}{cc}- & \text { Rhipicephalus turanicus } \\
- & \text { Hyalomma sp } \\
\end{array}$ \\
\hline
\end{tabular}

\section{CONCLUSION}

The results of the present study revealed that there is an infestation of ectoparasites in hedgehog and due to zoonotic importance of the transmission of some important pathogens; more studies are needed to find out hedgehog ectoparasites in other parts of Egypt. Also, our results suggest that pet owners especially those keep hedgehog should be aware about the hazards that may pose by these animals. Therefore, taking care including washing hands after handling them and using pesticides for eliminating ectoparasites will reduce the risk of catching zoonotic diseases from their hedgehogs.

\section{REFERENCES}

[1] Foldvari, G.; K. Rigo; M. Jablonszky; N. Biro; G. Majoros; V. Molnar and M. Toth (2011). Ticks and The city: ectoparasites of the Northern white-breasted Hedgehog (Erinaceus roumanicus) in an urban park. Ticks Tick Borne Dis. 2: 231-234.

[2] Jassim, S.Y (2017). The ixodid ticks of the long-eared hedgehog Hemiechinus Auritus (Gmelin, 1770) in Baghdad area, International Journal of Science and Research (IJSR). 6 (6): 2522- 2523.

[3] Nematollahi, A.; J. A. Helan; H. Golezardy; N. Zaboli; M. Nouruzi and M. Azari (2014). Parasitic fauna of east european hedgehog (Erinaceus Concolor) and their pathological aspects in Iran, Advances in Zoology and Botany 2(1): 1-5.

[4] McCarthy J. and T.A. Moore (2000). Emerging helminth zoonoses. Int., J. Parasitol.; 30:1351-1360.

[5] Mizgajska-Wiktor, H.; W. Jarosz; B. Piłacińska and S. Dziemian (2010). Helminths of hedgehogs, Erinaceus europaeus and E. roumanicus from Poznań region, Poland-coprologica study. Wiadomoceci Parazytologiczne.; 56: 329-332.

[6] Silaghi, C.; J. Skuballa; C. Thiel; K. Pfister; T. Petney; M. Pfaffle; H. Taraschewski and L. Passos (2012). The European hedgehog (Erinaceus europaeus) - a suitable reservoir for variants of Anaplasma phagocytophilum. Ticks Tick Borne Dis.; 3: 49-54. 
[7] Walker, A.R; A. Bouattour; J.L. Camicas; A. Estrada-Peña; I.G. Horak; A.A. Latif; R.G. Pegram and P.M. Preston (2007). Ticks of domestic animals in Africa: a guide to identification of species. Biosciences report, 1-22.

Citation: Abd El-Aleem S. S. Desoky., et.al," A prevalence study of ectoparasites on the long-eared hedgehog (Hemiechinus auritus) in Sohag Governorate, Egypt", International Journal of Research Studies in Zoology, vol. 5, no. 3, p. 33-35, 2019. DOI: http://dx.doi.org/10.20431/2454-941X.0503004

Copyright: () 2019 Authors. This is an open-access article distributed under the terms of the Creative Commons Attribution License, which permits unrestricted use, distribution, and reproduction in any medium, provided the original author and source are credited. 